\title{
EFFECT OF SUPPLEMENTATION DIETARY DRY FAT ON PRODUCTIVE AND REPRODUCTIVE PERFORMANCE ON EGYPTIAN LACTATING BUFFALOES
}

\author{
Kh.I.I. Zeedan'; M.A. Abdel-Latif ${ }^{2}$; E.A. El-Bltagy ${ }^{3}$, S.I. Weld Abd-Elkader ${ }^{1}$, A.A. El- \\ Giziry $^{1}$ and A. H. Ghoniem ${ }^{1}$ \\ ${ }^{1}$ Department of Animal Nutrition Res. ${ }^{2}$ Department of Buffalo Res. And ${ }^{3}$ By-product utilization \\ Animal Production Research Institute, Agricultural Research Centre, Dokki, Giza, Egypt.
}

(Received 12/10/2016, Accepted 17/11/2016)

\section{SUMMARY}

\begin{abstract}
$\mathrm{T}$ he present work was conducted to study the effect of using two levels of dry fat (DF 3 and 5\%) supplementation during pre-partum (three months before parturition) and after parturition period (six months after postpartum for Egyptian lactating buffalo-cows on nutritive values, nutrients digestibility, ruminal characteristics, milk yield and its composition, birth weight of their offspring, some reproductive parameters, some blood parameters and economic efficiency. Fifteen buffalo-cows (2-4 lactation seasons) in late pregnancy period were choosed to carry out this experiment. Animals were divided into three equal groups (5 buffaloes in each) and individually fed according to Kearl (1982). Concentrate feed mixture (CFM), berseem hay $(\mathrm{BH})$ and rice straw (RS) were given to animals as a control ration without supplementation $(\mathrm{C})$, while the other two groups received the control ration supplemented with DFat the levels of 3 and 5\% dry protected fat as calcium salt of fatty acids (based on DM intake), respectively. The obtained results could be summarized as follows: Supplementing buffalo cows ration DF improved the digestibility of all nutrients (pre and post-partum) and nutritive value which recording: 55.91, 61.37 and $66.87 \%$, TDN at 50 days and 58.40, 64.10 and $70.71 \%$, TDN at 180 days for $\mathrm{C}, \mathrm{DF}_{3}$ and $\mathrm{DF}_{5}$, respectively; the respective values of DCP was 7.16, 7.47 and $8.04 \%$ for the pre-partum period and $7.32,7.72$ and $8.39 \%$ for the post-partum period), respectively. Dry fat treatment led to increases in both birth, weaning weights and total gain of calves, and the highest best weights were occurred with $\mathrm{DF}_{5}$. Actual milk yield was increased as $8.50,9.30$ and $10.50 \mathrm{~kg} / \mathrm{day}$ for $\mathrm{C}_{,} \mathrm{DF}_{3}$ and $\mathrm{DF}_{5}$, respectively and 7\% - FCM yield on the same order were $7.92,9.81$ and $12.44 \mathrm{~kg} /$ day, with significant differences only due to the addition of $\mathrm{DF}_{3}$ and $\mathrm{DF}_{5}$ compared with $\mathrm{C}$. Dry fat improved the blood contents of, total protein, globulin, and glucose and increased in total lipids, cholesterol and HDL. The periods required for fetal membrane expulsion was significantly $(\mathrm{P}<0.05)$ reduced in $\mathrm{DF}_{3}(9.20 \mathrm{~h})$ and $\mathrm{DF}_{5}(7.15 \mathrm{~h})$ groups when compared to the $\mathrm{C}$ group (10.12 h).Moreover, only $\mathrm{C}$ group showed a case of abortion and stillbirth, while treated buffalo - cows of DF delivered $100 \%$ healthy calves. Better feed and economic efficiencies were observed with animals fed supplemented $\mathrm{DF}_{5}$. Generally, from the obtained results could be concluded that the supplementation of $\mathrm{DF}$ at $\mathrm{DF}_{3}$ and $\mathrm{DF}_{5}$ levels for ration of Egyptian lactating buffalo cows had positive effects on nutritive value, digestibility calves birth weight and milk yield and composition, beside better feed efficiency and reproductive performance as well as improved economic efficiency. The best and the highest results were obtained with the addition of $\mathrm{DF}_{5}$.
\end{abstract}

Keywords: Buffaloes, dry fat, pre-partum, post-partum, performance and reproductive, blood, milk yield, digestibility, rumen fermentation, economic efficiencies.

\section{INTRODUCTION}

In Egypt, buffaloes are considered the main source of milk production; they contribute about $70 \%$ of the total milk production in the country. Egyptian buffaloes contribute to about 5 and $14 \%$ of the world buffalo's milk and meat, respectively (FAO, 1990). As a rule, negative energy balance (NEB) is a physiological stage experienced by dairy cows after giving birth and is caused by the voluntary intake of feed which is insufficient for the nutritional requirements of the animal during this period. Decrease in voluntary consumption causes less amount of energy, reduction in the supply of nutrients, such as protein and minerals. Negative energy balance phenomenon during the post-partum period should be coped with as a phase which may bring production and reproduction disorders if it is not minimized National Research Council (NRC, 2001). Zeedan, et al. (2010) revealed that supplementation of dry fat to diets of 


\section{Zeedan et al.}

lactating Damascus goats at different levels (3 or 5\%) had positive effects on nutritive values, digestion, rumen fermentation, milk production consequently does productive performance as well as higher some traits of reproductive performance. Also, they reported that using fat can avoid some problem such as ruminal acidosis and liver abscess. Hafez (2012) stated that supplementing per parturient lactating buffalo with protected fat (300 g/day) increase milk production efficiency, $4 \%$ fat corrected milk yield was higher $(\mathrm{P} \leq 0.05)$ and enhance the feed efficiency throughout the first 100 day in lactation. Madan et al. (2013) showed that feeding of protected fat in buffaloes had a significant increase in milk yield and fat percentage was observed in treatment group as compared to control group.

Zeedan et al.(2014) recommended that using oil (O) and dry fat (DF) supplementation at levels (3\% $\mathrm{DM}$ intake $/ \mathrm{h} / \mathrm{d})$ ) in ration of Egyptian buffalo cows tended to improve the digestion, nutritive values, actual milk yield (AMY) and 7\% fat corrected milk yield (7\% FCM) and its composition, some blood constituents, some reproductive parameters and economic efficiencies. Singh et al. (2014) showed that addition of prill fat group (PFG) significantly increase milk yields and composition during supplemental of 90 days but no significantly in the dry matter intake. Safaa (2015) explained that supplementing buffaloes ration with different levels of DF (levels at 2 and 4\% based on DM intake) improved the digestibility coefficients of all nutrients, TDN, DCP and rumen liquor parameters without hazards effects on microflora. Dry fat treatment led to an increase in both birth and weaning weights of newborn calves. Milk yield and $7 \%$ fat corrected milk yield and composition were increased by increasing supplemental DF levels, enhanced the blood parameters as a hemoglobin, packed cell volume (PCV), total protein, globulin and glucose levels. Economic efficiency was preferable with animals fed supplemented DF compared with a control group. Sharma et al. (2016) indicated that the transition period is a critical determinant of both productivity and profitability of a dairy farm. During this period, hormones and metabolites were significantly altered to mobilize the body reserves to meet energy requirement of fetus and lacto genesis. Also, they reported that the supplementation of prilled fat at this crucial stage may improve the milk production through increase in energy balance of buffaloes. Supplementation of prilled fat during pre-partum (at $100 \mathrm{~g} /$ day) and post-partum (at $150 \mathrm{~g} /$ day) period resulted in a significant increase in milk yield (MY) and milk fat content and energy balance without affecting milk protein, lactose, SNF and DMI in Murrah buffaloes.

El-Garhir et al. (2013) revealed that feeding rations included whole linseed (LS) or whole cotton seeds (WCS) significantly enhance the ovarian response and reproductive performance of dairy buffalo cows; change the fatty acids profile of blood serum and altering lipid metabolism. Ramteke, et al. (2014) found that protected fat during pre partum and early lactation significantly improved the birth weight of the calf. However, time required for the involution of uterus, onset of first postpartum heat, service period and number of artificial insemination (AI) per conception were significantly reduced due to feeding of rumen protected fat. Other postpartum complications like pyometra, dystocia, retention of placenta, metritis, mastitis and calf mortality were reduced to great extent. Blood serum and enzyme profile were similar in both the group was statistically lower in bypass fat supplemented group.

The main objective of this study was to evaluate the response of Egyptian buffaloes during prepartum and postpartum to diets containing dry fat on nutrient digestibility and feeding value, birth weight of their offspring, milk yield and composition, some blood constituents, some reproductive parameters and economic efficiency.

\section{MATERIALS AND METHODS}

\section{The experimental procedures}

This study was carried out at El-Gemmaiza Experimental Station belonging to Animal Production Research Institute, Agricultural Research Centre. Fifteen lactating Egyptian buffalo-cows (2-4 lactation seasons) were used in this study. Animals were chosen in late pregnancy (LP) period at approximately 90 days pre-partum and divided randomly into three comparable experimental groups (5 animals per each group) to evaluate the effect of using dry fat (DF) in feeding buffalo cows on nutritive values, nutrients digestibility, ruminal parameters, milk yield and its composition, birth weight of their offspring, some blood parameters, some reproductive parameters and economic efficiency. The control (C) ration consisted of concentrate feed mixture $(\mathrm{CFM})$, berseem hay $(\mathrm{BH})$ and rice straw (RS) without supplementation dry fat, while the other two groups $\left(\mathrm{DF}_{3}\right)$ and $\left(\mathrm{DF}_{5}\right)$ received the control ration supplemented with dry or protected fat (DF) at the levels of 3 and 5\% DF (based on DM intake), respectively. Dry fat composed of calcium salt for fatty acids, plant origin 95\%, moisture $4.98 \%$, 
antioxidant BHT $0.02 \%$,crude fat $80 \%$, gross energy $7600 \mathrm{kal} / \mathrm{kg}$, TDN $180 \%$, digestion coefficient $95 \%$, constancy degree $96 \%$ and stearic acid $<5 \%$ ). Dry fat (DF) was well mixed with some of the ground concentrates feed mixture before feeding. Animals were individually fed according to Kearl (1982). Animals were left for 4 weeks as a preliminary period. The experimental treatments lasted nine months (three months before the expected calving date and continued up to six months of lactation period).

\section{Management and feeding}

Animals were housed in semi open pens until time of delivery then they were transferred to the maternity unit. Water was offered freely in troughs except at the milking time. After delivery, all buffalo cows were allowed to nurse their calves for only one week postpartum (period of colostrum), thereafter, the dams were transferred to the milking unit and milked twice daily at 7 a.m. and 5 p.m. and they were subjected to the regular managerial practices. Dams were weighed before and after calving as well as their new born calves were also weighed and recorded after calving until weaning (90 days). Milk yield was recorded. Representative samples of milk (morning and evening samples) were mixed and analyzed biweekly for fat, protein, lactose, solids non-fat, total solids and ash and somatic cell count (SCC) using Milk scan apparatus (model/30 series type 10900 FOSS). Energy of milk was calculated using the formula of Overman and Sanmann $(1926)(\mathrm{Kcal}=115.3(2.51+$ fat \% $)$.

The formula of Raafat and Saleh (1962) $(7 \% \mathrm{FCM}=0.265$ milk yield +10.5 fat yield) was used to convert the actual milk yield to $7 \%$ fat corrected milk (FCM).

\section{Digestibility trials}

Two digestibility trials were carried out at 50 and 180 days of the feeding trials using buffalo cows from all groups to determine the nutrients digestibility and nutritive value of the experimental rations. Acid Insoluble Ash (AIA) technique according to Van Keulen and Young (1977) was used as a marker for the determination of the nutrients digestibility. Digestibilities of DM as well as all nutrients were determined with the following equations:

$\%$ Nutrient digestibility=100-(\% DM digestibility x \% Nutrient in feces $) / \%$ Nutrient in feed).

Fecal samples were collected from the rectum twice daily at 7:00 a.m and 5:00 p.m. starting at the $3^{\text {rd }}$ day of the collection period. Feed and feces samples were dried, ground and kept for later analysis. Chemical composition of the different feed ingredients and feces were analyzed according to AOAC (1995).

\section{Rumen parameters}

Rumen liquor samples were collected for four days at the end of the last digestibility trial from all animals by stomach tube attached to a vacuum pump, at two times (just before morning feeding and 4 hrs after feeding). Samples were strained in four folds of cheese cloth. $\mathrm{pH}$ was determined immediately using a digital $\mathrm{pH}$ meter. Ammonia-N was determined according to the modified semi-micro Kijeldehl digestion method AOAC (1995). Total volatile fatty acids were determined according to Eadie, et al. (1967).

\section{Blood parameters}

Blood samples were collected once monthly via the jugular vein from each buffalo cow during late pregnancy (LP) and postpartum period (PP). Blood plasma was separated after adding ethylene diamine tetra acetic acid (EDTA) and centrifuged at 4000 r.p.m. for 15 minutes, then stored at $-20 \mathrm{C}^{\circ}$ until analysis for the different blood parameters. Total protein, albumin was determined using commercial kits while globulin concentration was calculated by the difference between total protein and albumin concentrations. Glucose and enzyme activities liver function were assessed by measuring the activities of alanine aminotrandferase (AST), aspartate aminotrandferase (ALT). progesterone (P4), estradiol 17 $\beta$, total cholesterol, High Density Lipoprotein (HDL-cholesterol), Low Density Lipoprotein (LDLcholesterol and total lipids were determined using commercial kits (Produced by Bio-Diagnostics Company, Egypt).High Density Lipoprotein (HDL) concentration of each assayed sample plasma was calculated by subtracting the LDL value from its total cholesterol.

\section{Statistical analysis}

Data were statistically analyzed according to SPSS (2012) computer program using the following fixed model

$Y_{i j}=\mu+T_{i}+e_{i j}$ 
Where: $\mathrm{Y}_{\mathrm{ij}}=$ the observation. $\mu=$ Overall mean. $\mathrm{T}_{\mathrm{i}}=$ Effect of the treatments. $\mathrm{e}_{\mathrm{ij}}=$ Random error component assumed to be normally distributed. means.

Ducans's multiple range tests was performed (Duncan, 1955) to detect significant differences among

\section{RESULTS AND DISCUSSION}

\section{Chemical composition of feedstuffs}

In general, the present results of the chemical composition values of CFM, BH, RS and DF (Tables 1 and 2) are within the normal ranges reported in Egypt by several workers (Hassanien, 2010, Zeedan, et al. 2010 and 2014 and Safaa, 2015).

Table (1). The chemical composition of feed ingredients and calculated composition of the experimental rations.

\begin{tabular}{|c|c|c|c|c|c|c|c|}
\hline \multirow{2}{*}{ Item } & \multicolumn{7}{|c|}{ Chemical composition as DM basis (\%) } \\
\hline & DM & OM & CP & $\mathrm{CF}$ & EE & Ash & NFE \\
\hline \multicolumn{8}{|c|}{ Chemical composition of the ingredients } \\
\hline CFM* & 91.81 & 94.40 & 16.34 & 11.75 & 3. 14 & 5.60 & 63.17 \\
\hline BH & 89.31 & 83.51 & 13.91 & 24.86 & 1.43 & 16.49 & 43.31 \\
\hline $\mathrm{RS}$ & 90.31 & 81.85 & 2.89 & 41.22 & 1.23 & 18.15 & 36.51 \\
\hline \multicolumn{8}{|c|}{ Calculated chemical composition of tested rations } \\
\hline $\mathrm{C}$ & 90.77 & 87.73 & 12.76 & 23.24 & 2.24 & 12.27 & 49.49 \\
\hline $\mathrm{DF}_{3}$ & 90.78 & 87.85 & 12.91 & 23.27 & 5.27 & 12.15 & 46.40 \\
\hline $\mathrm{DF}_{5}$ & 90.80 & 88.59 & 13.21 & 23.29 & 7.29 & 11.41 & 44.80 \\
\hline
\end{tabular}

${ }^{*}$ CFM; concentrate feed mix contained in percentage ; $37 \%$ yellow corn, $30 \%$ undecorticated cotton seed , $20 \%$ wheat bran, $6.5 \%$ rice bran, $3 \%$ molasses, $2.5 \%$ limestone, $1 \%$ common salt.

$C=$ Control, $D F 3=3 \% D F$ (basedon DM intake) and DF5=5\% DF (basedon DM intake).

Table (2). Fatty acids composition in dry fat (DF) used in the present study.

\begin{tabular}{llllllllll}
\hline Fatty acid & Leuric & Myristic & Palmitic & Stearic & Oleic & Linoleic & Linoleinic & Arachidonic & others \\
& $\mathrm{C}_{12: 0}$ & C14: 0 & C16: 0 & C18: 0 & C18: 1 & C18: 2 & C18: 3 & C20: 0 & \\
\hline Dry fat (DF) & 50.48 & 2.89 & 10.96 & 3.17 & 5.48 & 1.10 & 12.27 & 10.88 & 2.77 \\
\hline
\end{tabular}

\section{Digestibility and feeding values}

Data in Table (3) indicated that digestion coefficients and nutritive value (TDN and DCP) at 50 and 180 days tended to increase for same nutrients of $\mathrm{DF}_{3}$ and $\mathrm{DF}_{5}$ compared to $\mathrm{C}$, while $\mathrm{DF}_{5}$ recorded the highest values compared to $\mathrm{DF}_{3}$ and C. Similar results were obtained by (Zeedan, et al. 2010 and. 2014), who found that adding dry fat in the form of Ca-soap in milking Damascus goats and Egyptian buffalo cows diets showed higher digestibility of DM, OM, CP, EE, NFE and CF than control during late pregnancy (LP) stages and milking production. These results are in agreement with those obtained by Gabr et al. (2008) and Safaa (2015). Souza Júnior et al. (2016) showed that protected fat (MEGALAC) increased $(\mathrm{P}<0.05)$ the digestibility of DM, OM, CP, ashes, EE and TDN in the lower protein $(12 \%)$ content. In this study the increased in EE digestibility could be due to the higher digestibility of fatty acids in supplementary fat. Hassanien (2010) found that addition of dry fat (3and 5\%) was highly significantly in digestion of $\mathrm{CP}, \mathrm{EE}$ and $\mathrm{CF}$ compared the control group. Also; fat treatments significantly improved the nutritive value as TDN and DCP. Values of TDN were 57.04, 60.72 and $66.19 \%$ for $\mathrm{R}_{0}, \mathrm{R}_{3}$ and $\mathrm{R}_{5}$, respectively. 
Table (3). Effect of dry fat (DF) supplementation on nutrients digestibility and feeding value of the experimental rations fed to Egyptian buffalo cows.

\begin{tabular}{|c|c|c|c|c|c|c|c|c|}
\hline \multirow{2}{*}{ Item } & \multicolumn{3}{|c|}{50 Days } & \multirow{2}{*}{ SEM } & \multicolumn{3}{|c|}{180 Days } & \multirow{2}{*}{ SEM } \\
\hline & $\mathrm{C}$ & $\mathrm{DF}_{3}$ & $\mathrm{DF}_{5}$ & & $\mathrm{C}$ & $\mathrm{DF}_{3}$ & $\mathrm{DF}_{5}$ & \\
\hline \multicolumn{9}{|c|}{ Digestion coefficients (\%) } \\
\hline DM & $60.17^{\mathrm{b}}$ & $63.24^{\mathrm{b}}$ & $66.24^{\mathrm{a}}$ & 0.51 & $65.12^{\mathrm{b}}$ & $66.15^{\mathrm{b}}$ & $70.13^{\mathrm{a}}$ & 0.33 \\
\hline OM & $63.84^{\mathrm{b}}$ & $65.19^{\mathrm{ab}}$ & $67.98^{\mathrm{a}}$ & 0.29 & $65.91^{\mathrm{b}}$ & $68.33^{\mathrm{ab}}$ & $70.78^{\mathrm{a}}$ & 0.50 \\
\hline $\mathrm{CP}$ & $56.14^{\mathrm{b}}$ & $57.86^{\mathrm{b}}$ & $60.87^{\mathrm{a}}$ & 0.10 & $57.37^{\mathrm{b}}$ & $59.83^{\mathrm{b}}$ & $63.48^{\mathrm{a}}$ & 0.40 \\
\hline $\mathrm{CF}$ & $49.79^{b}$ & $51.46^{\mathrm{b}}$ & $55.23^{\mathrm{a}}$ & 0.08 & $51.65^{\mathrm{b}}$ & $53.89^{\mathrm{ab}}$ & $56.95^{\mathrm{a}}$ & 0.12 \\
\hline $\mathrm{EE}$ & $82.09^{\mathrm{b}}$ & $85.20^{\mathrm{ab}}$ & $87.93^{\mathrm{a}}$ & 0.09 & $84.68^{\mathrm{b}}$ & $86.95^{\mathrm{b}}$ & $90.17^{\mathrm{a}}$ & 0.42 \\
\hline NFE & $66.13^{b}$ & $67.92^{\mathrm{ab}}$ & $70.35^{\mathrm{a}}$ & 0.45 & $69.98^{\mathrm{b}}$ & $71.56^{\mathrm{b}}$ & $76.43^{\mathrm{a}}$ & 0.32 \\
\hline \multicolumn{9}{|c|}{ Feeding value (\%) } \\
\hline TDN & $55.91^{\mathrm{c}}$ & $61.37^{\mathrm{b}}$ & $66.87^{\mathrm{a}}$ & 0.42 & $58.40^{\mathrm{c}}$ & $64.10^{\mathrm{b}}$ & $70.71^{\mathrm{a}}$ & 0.12 \\
\hline DCP & $7.16^{\mathrm{b}}$ & $7.47^{\mathrm{ab}}$ & $8.04^{\mathrm{a}}$ & 0.01 & $7.32^{\mathrm{b}}$ & $7.72^{\mathrm{ab}}$ & $8.39^{\mathrm{a}}$ & 0.01 \\
\hline
\end{tabular}

Abu El-Hamd et al. (2012) reported that crude protein and ether extract digestion were higher $(\mathrm{P}<0.05)$ in supplementation with 5\% protected fat (G2) than in control (G1). They reported that the total digestible nutrients (TDN \%) was higher $(\mathrm{P}<0.05)$ in $\mathrm{G} 2$ than in $\mathrm{G} 1$. Generally, the improvement of feeding values in protected fat was attributed to higher digestibility coefficients in G2 than in G1.In current study, the improvement of TDN might be due to the higher values of digestibility values of most nutrients by supplementation especially EE digestibility, corroborating results by Gabr et al. (2008), Zeedan, et al. (2010), Zeedan, et al. (2014), Safaa (2015) and Souza Júnior et al. (2016). Singh et al. (2014) showed that total digestible nutrients (TDN) was significantly higher $(\mathrm{P}<0.05)$ in addition of prill fat group (PFG) cows than the control cows. On the other hand, Rennó, et al. (2014) reported that supplementation of unsaturated fatty acids had no effects on DM, OM, CP, and NDF in the pre-partum period. Abu El-Hamd et al. (2012) suggested that digestibility coefficients of DM, OM, CF, NFE and DCP value were not affected by supplementing CFM with protected fat at 5\%.

\section{Rumen parameters}

Ruminal $\mathrm{pH}$ value is one of the most important factors, which affect microbial fermentation in the rumen and influenced its functions. . However, data presented in Table (4) illustrated that $\mathrm{pH}$ values were not significantly different among the experimental groups. $\mathrm{But} \mathrm{pH}$ value was decreased after feeding in all groups.

Table (4). Effect of dry fat (DF) supplementation on some rumen liquor parameters of lactating buffalo cows.

\begin{tabular}{lccccc}
\hline Item & Time & $\mathrm{C}$ & $\mathrm{DF}_{3}$ & $\mathrm{DF}_{5}$ & SEM \\
\hline $\mathrm{pH}$ & 0 & 6.68 & 6.45 & 6.29 & 0.42 \\
& 4 & 6.34 & 6.04 & 5.73 & 0.50 \\
Ammonia-N mg/100ml & 0 & $13.73^{\mathrm{a}}$ & $11.53^{\mathrm{c}}$ & $12.89^{\mathrm{b}}$ & 0.10 \\
& 4 & $15.64^{\mathrm{a}}$ & $14.91^{\mathrm{b}}$ & $13.57^{\mathrm{c}}$ & 0.08 \\
Total VFA meq/100ml & 0 & $8.34^{\mathrm{a}}$ & $7.69^{\mathrm{b}}$ & $6.49^{\mathrm{c}}$ & 0.02 \\
& 4 & $13.15^{\mathrm{a}}$ & $12.14^{\mathrm{b}}$ & $11.55^{\mathrm{c}}$ & 0.01 \\
\hline
\end{tabular}

Means bearing different superscripts in the same raw are significantly different $(P<0.05)$.

$C=$ Control, $D F 3=3 \%$ DF (basedon DM intake) and DF5=5\% DF (basedon DM intake).

Similar results were reported by Hassanien (2010), Zeedan, et al. (2010) and Safaa (2015). Kholif et al. (2015) showed that ruminal liquor $\mathrm{pH}$ was decreased $(\mathrm{P}<0.05)$ for animals fed control ration +20 $\mathrm{ml} / \mathrm{head} /$ day linseed oil (LO) and control ration $+50 \mathrm{~g} / \mathrm{head} /$ day crushed linseed (LS) and then control in lactating goats. On the other hand, Abu El-Hamd et al. (2012) reported that the pH value was higher $(\mathrm{P}<0.001)$ in cows fed ration supplemented with $5 \%$ protected fat $(\mathrm{G} 2,6.06)$ than of control $(\mathrm{G} 1,5.83)$. 


\section{Zeedan et al.}

Data of $\mathrm{NH}_{3}-\mathrm{N}$ concentration was significantly $(\mathrm{P}<0.05)$ decreased for animals fed supplemented DF compared to the control group $(\mathrm{C})$, while ammonia-N was increased $(\mathrm{P}<0.05)$ at $4 \mathrm{hrs}$ post - feeding shown Table (4). These results are in agreement with those reported by Hassanien (2010), Abu El-Hamd et al. (2012) and Safaa (2015). Concentration of NH3-N was significantly higher $(\mathrm{P}<0.05)$ for the control group than the fat supplementation groups both $\mathrm{DF}_{3}$ and $\mathrm{DF}_{5}$. The higher $\mathrm{NH} 3-\mathrm{N}$ values reported in the control group may be due, at least in part, to a higher rate of protein breakdown within the rumen, or to a better utilization in the fat-treated groups. Kholif et al. (2015) showed that rumen ammonia-N was lower $(\mathrm{P}<0.05)$ for animals fed control ration $+20 \mathrm{ml} / \mathrm{head} /$ day linseed oil $(\mathrm{LO})$ and control $\mathrm{ration}+50 \mathrm{~g} / \mathrm{head} / \mathrm{day}$ crushed linseed (LS) compared to control in lactating goats. On the other hand, Zeedan et al. (2010) found that the addition of dry fat to diets of lactating Damascus goats at different levels (3 or 5\%) increased rumen ammonia - N compared to control one but it not reached the significant effect. Rennó et al. (2014) pointed that supplementation of cows fed soybean oil (SO), based on inclusion of $30 \mathrm{~g} / \mathrm{kg}$ (DM basis); and calcium salts of unsaturated fatty acids (CS), based on inclusion of $30 \mathrm{~g} / \mathrm{kg}$ (DM Basis) in the pre-partum and post-partum period, had no effect on the concentrations of rumen N-NH3 concentrations.

In current study, the TVFA's have the consistency of the same pattern of $\mathrm{NH}_{3}-\mathrm{N}$ for pre and at 4 hrs post -feeding shown Table (4).Corroborating results by Gabr et al. (2008), Hassanien, (2010) and Safaa, (2015).The published articles have some conflicts regarding the effect of dietary fat on ruminal VFA concentration. Differences may have been due to different factors such as the form and/or level of fat used, the level of the dietary energy, the other ingredients in the diet, feeding frequency, roughage to concentrate ratio etc. Zeedan et al. (2010) showed that there were high significant differences at $(\mathrm{P}<0.05)$ among the tested groups for total VFA at $3 \mathrm{hr}$ post feeding being $11.35,12.92$ and $13.09 \mathrm{meq} / 100 \mathrm{ml}$ for control, 3 and 5\%DF groups, respectively. While, not significant effect was determined at zero time between treatments. Abu El-Hamd et al. (2012) reported that the rumen VFA concentration was not affect by dietary treatment with cows of $5 \%$ protected fat $(\mathrm{G} 2,13.63 \mathrm{meq} / 100 \mathrm{ml}$ rumen liquor) an control one (G1, $14.15 \mathrm{meq} / 100 \mathrm{ml}$ rumen liquor). Kholif, et al. (2015) showed that total VFA was increased $(\mathrm{P}<0.05)$ for animals fed $(\mathrm{LO})$ and $(\mathrm{LS})$ compared to control in lactating goats.

\section{Birth weight of born calves and dams}

Data of body weight (dams and their calves) and daily gain of calves are presented in Table (5). Differences respecting the dam body weight at late pregnancy (LP) were insignificant among experimental groups. Percentages of CBW / Dam post-partum were increased significantly $(\mathrm{P} \leq 0.05)$ due to DF compared with $\mathrm{C}$ and calves is very heavier at birth (Table5). Weaning weight, total gain and daily gain of calve were significant increased by addition $\mathrm{DF}$ with the highest value for $\mathrm{DF}_{5}$. Improvement was 9.1 and $27.27 \%$ for daily gain of calves $\mathrm{DF}_{3}$ and $\mathrm{DF}_{5}$, respectively.

Table (5). Effect of dry fat (DF) supplementation on body weight of Egyptian buffalo cows and new born calves.

\begin{tabular}{lcccc}
\hline Item & $\mathrm{C}$ & $\mathrm{DF}_{3}$ & $\mathrm{DF}_{5}$ & SEM \\
\hline Dam body weight LP (DBW) kg & 572 & 575 & 577 & 2.77 \\
Dam body weight PP (kg) & $510^{\mathrm{a}}$ & $500^{\mathrm{b}}$ & $490^{\mathrm{c}}$ & 5.22 \\
Calf birth weight (CBW) kg & $38^{\mathrm{c}}$ & $43^{\mathrm{b}}$ & $47^{\mathrm{a}}$ & 0.06 \\
CBW / Dam post-partum (\%) & $7.45^{\mathrm{b}}$ & $8.60^{\mathrm{b}}$ & $9.59^{\mathrm{a}}$ & 0.02 \\
Calf weaning weight (kg) & $88^{\mathrm{c}}$ & $97^{\mathrm{b}}$ & $110^{\mathrm{a}}$ & 0.60 \\
Total gain of calve (kg) & $50^{\mathrm{b}}$ & $54^{\mathrm{b}}$ & $63^{\mathrm{a}}$ & 0.10 \\
Daily gain of calve (g/day) & $0.55^{\mathrm{b}}$ & $0.60^{\mathrm{ab}}$ & $0.70^{\mathrm{a}}$ & 0.01 \\
Improvement gain of calves \% & - & 9.10 & 27.27 & -- \\
\hline
\end{tabular}

Means bearing different superscripts in the same raw are significantly different $(P<0.05)$.

$C=$ Control, $D F 3=3 \%$ DF (basedon DM intake) and DF5=5\% DF (basedon DM intake).

$L P=$ late pregnancy $\quad P P=$ postpartum period

The supplementation of DF increased the digestible protein, TDN, milk protein and milk lactose which led to increase the calf birth weight and calf weaning weight. This was in consistent with the results of Zeedan et al. (2010 and 2014), Toufighi et al. (2014) and Safaa (2015). Gabr et al. (2008) who reported that addition of fish oil for ewes diets during nursing resulted in improving its feed utilization and resulted in satisfactory ewe live weight and lamb growth rate. Also, Toufighi et al. (2014) stated that rumen-protected fat (RPF 3 or 5\%) supplementation to the young bulls had positive effects on growth 
performance [BWG and feed conversion ratio (FCR)]. Ramteke, et al. (2014) found that protected fat during prepartum and early lactation significantly improved the birth weight of the calf. In contrast, the findings of Fiorentini et al. (2014) pointed that the ADG did not differ between the animals fed the linseed oil (LO), protected fat (PF) and whole soybeans (WS).

\section{Milk yield and composition}

The actual milk yield (AMY) and $7 \%$ fat corrected milk (7\% FCM) yield were significant $(\mathrm{P} \leq 0.05)$ higher of DF than those of the $\mathrm{C}$ (Table 6). Improved daily milk yield were 9.41 and 23.53 and $7 \%$ fat correct milk yield (FCM) 23.86 and $57.10 \%$, compared to control group. These results agree with the findings of Gabr et al. (2008), Zeedan et al. (2014) and Safaa (2015). In current study, corroborating results by Zeedan et al. (2010) who found that supplementation of dry fat to diets of Damascus goats at different levels (3 or 5\%) had positive and beneficial effects on milk production and composition.

Table (6). Effect of dry fat (DF) supplementation on milk yield and composition of lactating Egyptian buffalo cows.

\begin{tabular}{lcccc}
\hline Item & $\mathrm{C}$ & $\mathrm{DF}_{3}$ & $\mathrm{DF}_{5}$ & SEM \\
\hline Actual milk yield (AMY), kg / day & $8.50^{\mathrm{c}}$ & $9.30^{\mathrm{b}}$ & $10.50^{\mathrm{a}}$ & 0.10 \\
Improvement Actual milk yield\% & - & 9.41 & 23.53 & - \\
7\% fat correct milk yield (FCM), kg / day & $7.92^{\mathrm{c}}$ & $9.81^{\mathrm{b}}$ & $12.44^{\mathrm{a}}$ & 0.08 \\
Improvement7\% fat correct milk yield (FCM)\% & - & 23.86 & 57.10 & - \\
Milk composition ( \% ) & & & \\
Fat, \% & $6.30^{\mathrm{c}}$ & $7.50^{\mathrm{b}}$ & $8.80^{\mathrm{a}}$ & 0.01 \\
Fat yield (kg) & $0.54^{\mathrm{c}}$ & $0.70^{\mathrm{b}}$ & $0.92^{\mathrm{a}}$ & 0.02 \\
Protein, \% & $4.12^{\mathrm{b}}$ & $4.35^{\mathrm{b}}$ & $5.07^{\mathrm{a}}$ & 0.01 \\
Protein yield (kg) & $0.35^{\mathrm{c}}$ & $0.41^{\mathrm{b}}$ & $0.53^{\mathrm{a}}$ & 0.01 \\
Lactose, \% & $3.82^{\mathrm{c}}$ & $4.18^{\mathrm{b}}$ & $4.57^{\mathrm{a}}$ & 0.03 \\
Solid non fat (SNF), \% & $8.80^{\mathrm{c}}$ & $9.21^{\mathrm{b}}$ & $10.18^{\mathrm{a}}$ & 0.07 \\
Total solid (T.S), \% & $15.10^{\mathrm{b}}$ & $16.71^{\mathrm{b}}$ & $18.98^{\mathrm{a}}$ & 0.17 \\
Ash, \% & $0.86^{\mathrm{a}}$ & $0.68^{\mathrm{b}}$ & $0.54^{\mathrm{c}}$ & 0.01 \\
Milk energy (Kcal / Kg milk) & $1016^{\mathrm{c}}$ & $1154^{\mathrm{b}}$ & $1304^{\mathrm{a}}$ & 10.30 \\
Somatic cell count (SCC) x 10\% ml milk & $430^{\mathrm{a}}$ & $380^{\mathrm{b}}$ & $335^{\mathrm{c}}$ & 5.44 \\
\hline
\end{tabular}

Means bearing different superscripts in the same raw are significantly different $(P<0.05)$.

$C=$ Control, DF3=3\% DF (basedon DM intake) and DF5=5\% DF (basedon DM intake).

Abu El-Hamd et al. (2012) suggested that 4\% fat corrected milk yield (FCMY) were higher (P $\leq 0.05)$ by 10.34 and $21.99 \%$ for supplementation with $5 \%$ protected fat (G2) than in control (G1). Hafez (2012) stated that supplementing pre-partum lactating buffalo with protected fat (300 g/day) increased milk production efficiency also, $4 \%$ fat corrected milk yield was higher $(\mathrm{P} \leq 0.05)$. Madan et al. (2013) showed that feeding of protected fat in buffaloes had a significant increase in milk yield by $18.68 \%$ compared to control group. Singh et al. (2014) showed that addition of prill fat group (PFG) significantly increased milk yields and composition during supplemental of 90 days. Kholif et al. (2015) showed that milk yield were higher $(\mathrm{P}<0.05)$ for animals fed control ration $+20 \mathrm{ml} / \mathrm{head} /$ day linseed oil $(\mathrm{LO})$ followed by control ration $+50 \mathrm{~g} / \mathrm{head} /$ day crushed linseed (LS) and then control for 90 days in lactating goats. Sharma et al. (2016) indicated that milk yield (MY) was higher $(\mathrm{p}<0.01)$ in supplemented group [SG] ( prilled fat at 100 $\mathrm{g}$ /day for 35 days pre-partum and at $150 \mathrm{~g}$ /day for 95 days post-partum) than control group [CG] during 95 days of early lactation. Milk fat, fat corrected and MY was higher $(\mathrm{P}<0.01)$ in SG. On contrary, the results of Abu El-Hamd et al. (2012) suggested that average daily milk yield (ADMY) was not affected by supplementation with $5 \%$ protected fat (G2) than in control (G1). Rennó et al. (2014) pointed that no difference was detected for milk yield (MY) between cows supplemented or un-supplemented with unsaturated fatty acids. Souza Júnior et al. (2016) suggested that there was no difference $(\mathrm{P}>0.05)$ on milk yield due to protected fat or CP rates.

Percentages of milk constituents (fat, protein, lactose, SNF, TS and milk energy) were significantly $(\mathrm{P} \leq 0.05)$ higher in groups DF than those of $\mathrm{C}$ as shown in (Table 6). Also, yields of milk fat, protein and lactose were increased significantly due to both DF additions than those of C. Similar results were obtained by Zeedan et al. (2010 and 2014) and Safaa (2015). In the same trend, ewes had higher TS, fat, SNF and lactose percentage when they fed diet supplemented with fish oil (Gabr et al. 2008). Abu ElHamd et al. (2012) suggested that percentage of fat and protein in milk cows were higher $(\mathrm{P} \leq 0.05)$ in 


\section{Zeedan et al.}

supplementation with $5 \%$ protected fat (G2) than in control (G1). Madan et al. (2013) showed that the milk protein, SNF, fat and lactose content $(\%)$ were increased in the animals of protected fat. Singh et al. (2014) showed that milk fat, protein and lactose were increased by $0.50 \mathrm{~kg} / \mathrm{d} / \mathrm{cow}$ in the supplemented cows (PFG) over the control $(\mathrm{CON})$. Kholif et al. (2015) showed that fat content was higher $(\mathrm{P}<0.05)$ with goats fed control ration $+20 \mathrm{ml} / \mathrm{head} /$ day linseed oil $(\mathrm{LO})$ followed by control $\mathrm{ration}+50 \mathrm{~g} / \mathrm{head} / \mathrm{day}$ crushed linseed (LS) and then the control. Protein content was increased $(\mathrm{P}<0.05)$ with LO compared to control, without significant differences between LS and control.

On the other hand, Abu El-Hamd et al. (2012) suggested that percentages of lactose, total solids and solid not fats were not affected by supplementation with $5 \%$ protected fat than in control. Sharma et al. (2016) indicated that protein; lactose and solid not fat content did not varied between the groups. Souza Júnior et al. (2016) suggested no difference $(\mathrm{P}>0.05)$ on milk composition due to protected fat or $\mathrm{CP}$ rates. In current study, energy of milk was significantly $(\mathrm{P} \leq 0.05)$ higher in DF groups than those of corroborating results by Zeedan et al. (2014) and Safaa (2015).

The addition levels of DF significantly $(\mathrm{P} \leq 0.05)$ decreased somatic cell count $(\mathrm{SCC})$ compared with that of the $\mathrm{C}$ group (Table 6). Similar results were obtained by Abu El-Hamd et al. (2012), Zeedan et al. (2014) and Safaa (2015). On the other hand, Hafez (2012) stated that the SCC don't affect by protected fat (300 g/day).

Greater yields of fat, protein and lactose were found with DF-supplemented groups. This may be attributed to the more milk yield for Egyptian buffalo-cows fed DF. It could be probably also attributed to the higher concentration of blood plasma glucose and albumin for animals fed DF supplementation (Table 7). It could lead to an increase in milk lactose synthesis and a consequent in milk production. Adding fat to the diet increases digested energy of the diet and increases milk production. The DF may be directly absorbed in the lower tract and efficiently transferred to milk fat, similar results were obtained by Zeedan et al. (2010 and 2014) and Safaa (2015).

\section{Feed intake and feed efficiency}

Dry mater intake (DMI) was decreased with group supplemented with DF compared with the control group but without significant effect (Table 7). This is in consistent with the results of Gabr et al. (2008), Zeedan et al. (2010 and 2014) and Safaa (2015). It could be shown that DF supplementation perhaps make a favorable effect for animals to get the best ingredient from ration, and also tended to improve digestibility and nutritive value for experimental rations, thus led to an increase in utilization of rations.

Table (7). Effect of dry fat (DF) supplementation on feed intake and efficiency.

\begin{tabular}{lcccc}
\hline Item & $\mathrm{C}$ & $\mathrm{DF}_{3}$ & $\mathrm{DF}_{5}$ & SEM \\
\hline Daily DM intake $(\mathrm{Kg} / \mathrm{h} / \mathrm{d})$ as & & & & \\
CFM & 7.00 & 7.00 & 7.00 & - \\
BH & 4.00 & 4.00 & 4.00 & - \\
R.S & 3.00 & 2.80 & 2.40 & - \\
Total DMI & 14.00 & 13.80 & 13.40 & 0.65 \\
Total TDNI & 8.00 & 8.66 & 9.22 & 0.77 \\
Total DCPI & 1.01 & 1.05 & 1.10 & 0.05 \\
7\% fat correct milk yield (FCM), kg / day & $7.92^{\mathrm{c}}$ & $9.81^{\mathrm{b}}$ & $12.44^{\mathrm{a}}$ & 0.08 \\
Feed efficiency & & & \\
Milk yield / DMI & $0.61^{\mathrm{b}}$ & $0.67^{\mathrm{b}}$ & $0.78^{\mathrm{a}}$ & 0.01 \\
$7 \%$ FCM / kg DM & $0.57^{\mathrm{c}}$ & $0.71^{\mathrm{b}}$ & $0.93^{\mathrm{a}}$ & 0.04 \\
$7 \%$ FCM / kg TDNI & $0.99^{\mathrm{c}}$ & $1.13^{\mathrm{b}}$ & $1.35^{\mathrm{a}}$ & 0.01 \\
$7 \%$ FCM / kg DCPI & $7.84^{\mathrm{c}}$ & $9.34^{\mathrm{b}}$ & $11.31^{\mathrm{a}}$ & 0.06 \\
\hline
\end{tabular}

Means bearing different superscripts in the same raw are significantly different $(P<0.05)$.

$C=$ Control, $D F 3=3 \%$ DF (basedon DM intake) and DF5=5\% DF (basedon DM intake).

A portion of the increase in digestibility may have resulted from the reduction of DMI (Table 7) that occurred. Rennó et al. (2014) pointed that supplementation of unsaturated fatty acids had no effects on DM in the pre-partum period but in the post-partum period, cows fed CS and SO had lower intakes of DM.

Toufighi et al. (2014) found that in all experimental periods daily DMI were decreased for 3 or 5\% rumen-protected fat and the differences were not statistically significant. Kholif, et al. (2015) showed that dry mater intake (DMI) values were not affected between all treatments fed control ration +20 
$\mathrm{ml} /$ head/day linseed oil (LO) followed by control ration $+50 \mathrm{~g} / \mathrm{head} / \mathrm{day}$ crushed linseed (LS) and then the control in goats. Sharma et al. (2016) indicated that buffaloes consumed DM during post-partum between the groups (CG and SG) were non-significant. Souza Júnior et al. (2016) indicated that treatments (MEGALAC) had no effect on consumption of dry matter (DM). On the other hand; Abu El-Hamd et al. (2012) suggested that the average DM $(\mathrm{kg} / \mathrm{d} / \mathrm{h})$ during postpartum periods were higher in $\mathrm{G}_{2}$ than $\mathrm{G}_{1}$ of cows. Singh et al. (2014) showed that the dry matter intake was significantly more $(\mathrm{P}<0.05)$ in PFG group in comparison to Control. Sharma et al. (2016) indicated that Buffaloes of SG consumed more DMI $(\mathrm{P}<0.01)$ than the $\mathrm{CG}$ during pre-partum period.

Energy intake expressed as TDN and DCP was more for the DF supplemented groups than the control group but without significant effect. These results compatible with the conclusion reported by Zeedan et al. (2010 and 2014) and Safaa (2015). Abu El-Hamd et al. (2012) indicated that the average TDN and CP intakes $(\mathrm{kg} / \mathrm{d} / \mathrm{h})$ during postpartum periods were higher in $\mathrm{G}_{2}$ than $\mathrm{G}_{1}$ of cows. Singh et al. (2014) showed that the crude protein intake $(\mathrm{kg} / 100 \mathrm{~kg}$ b.wt.) was significantly more $(\mathrm{P}<0.05)$ in $\mathrm{PFG}$ group in comparison to Control.

Feed efficiency expressed as amounts of either actual milk or 7\% milk yields produced from one $\mathrm{kg}$ $\mathrm{DM}$ intake (Table 7) appeared to be $(\mathrm{P} \leq 0.05)$ higher for $\mathrm{DF}_{5}$ than those fed control ration. However, differences in feed efficiency between $\mathrm{DF}_{3}, \mathrm{DF}_{5}$ and $\mathrm{C}$ groups were significant. Improvement in feed efficiency for groups consumed DF supplementation might be attributed to lower DM intake, higher milk yield and improvement digestion coefficients and nutritive value (TDN and DCP). This was in consistent with the results Gabr et al. (2008), Zeedan et al. (2010) and Safaa (2015). Sharma et al. (2016) which indicated that the feed efficiency of the SG was higher $(\mathrm{P}<0.01)$ than the $\mathrm{CG}$ during the post-partum period.

\section{Blood parameters}

Data in Table (8) illustrated that significant $(\mathrm{P} \leq 0.05)$ differences were observed in total protein, albumin and globulin during LP and PP period. The increase in total protein, albumin and globulin with dry fat addition may be due to the increase in protein synthesis, and digestion of protein as show in Table (3).These findings agree with those of Gabr et al. (2008), Zeedan et al. (2010 and 2014) and Safaa (2015). On the other hand, Hassanien (2010) indicated that addition of dry fat (3and 5\%) were not affected $(\mathrm{P}>0.05)$ on plasma total protein, albumin and globulin.

Table (8). Effect of dry fat (DF) supplementation level on some blood plasma parameters during before (LP) and after (PP) calving.

\begin{tabular}{|c|c|c|c|c|c|c|c|c|}
\hline \multirow[t]{2}{*}{ Item } & \multicolumn{3}{|c|}{ LP } & \multirow[b]{2}{*}{ SEM } & \multicolumn{3}{|c|}{$\mathrm{PP}$} & \multirow[b]{2}{*}{ SEM } \\
\hline & $\mathrm{C}$ & $\mathrm{DF}_{3}$ & $\mathrm{DF}_{5}$ & & $\mathrm{C}$ & $\mathrm{DF}_{3}$ & $\mathrm{DF}_{5}$ & \\
\hline T. protein (g/dl) & $5.87^{\mathrm{c}}$ & $6.41^{b}$ & $6.79^{\mathrm{a}}$ & 0.07 & $6.08^{c}$ & $6.95^{b}$ & $7.49^{\mathrm{a}}$ & 0.05 \\
\hline Albumin $(\mathrm{A})(\mathrm{g} / \mathrm{dl})$ & $2.93^{\mathrm{b}}$ & $3.13^{\mathrm{ab}}$ & $3.39^{\mathrm{a}}$ & 0.01 & $3.07^{\mathrm{b}}$ & $3.66^{\mathrm{a}}$ & $3.94^{\mathrm{a}}$ & 0.02 \\
\hline Globulin $(\mathrm{G})(\mathrm{g} / \mathrm{dl})$ & $2.94^{\mathrm{b}}$ & $3.28^{\mathrm{a}}$ & $3.40^{\mathrm{a}}$ & 0.01 & $3.01^{\mathrm{c}}$ & $3.29^{\mathrm{b}}$ & $3.55^{\mathrm{a}}$ & 0.02 \\
\hline ALT (IU/L) & 84.19 & 84.32 & 84.51 & 0.88 & 85.85 & 85.89 & 86.01 & 0.44 \\
\hline AST (IU/L) & 23.41 & 23.39 & 23.43 & 0.25 & 23.99 & 23.45 & 23.40 & 0.18 \\
\hline Glucose(mg/dl) & $54.22^{\mathrm{b}}$ & $56.56^{\mathrm{b}}$ & $59.33^{\mathrm{a}}$ & 0.33 & $56.14^{\mathrm{c}}$ & $58.35^{\mathrm{b}}$ & $61.23^{\mathrm{a}}$ & 0.42 \\
\hline T. lipids (mg/dl) & $348^{\mathrm{c}}$ & $381^{\mathrm{b}}$ & $399^{\mathrm{a}}$ & 3.23 & $365^{\mathrm{c}}$ & $415^{\mathrm{b}}$ & $433^{\mathrm{a}}$ & 5.60 \\
\hline Cholesterol (mg/dl) & $79.23^{\mathrm{b}}$ & $84.81^{\mathrm{a}}$ & $87.04^{\mathrm{a}}$ & 3.00 & $80.77^{\mathrm{c}}$ & $86.57^{\mathrm{b}}$ & $92.47^{\mathrm{a}}$ & 0.75 \\
\hline $\mathrm{HDL}(\mathrm{mg} / \mathrm{dl})$ & $42.56^{\mathrm{b}}$ & $46.37^{\mathrm{a}}$ & $48.52^{\mathrm{a}}$ & 0.96 & $42.91^{\mathrm{b}}$ & $47.62^{\mathrm{a}}$ & $49.87^{\mathrm{a}}$ & 0.23 \\
\hline LDL (mg/dl) & $36.67^{\mathrm{b}}$ & $38.44^{\mathrm{a}}$ & $38.52^{\mathrm{a}}$ & 0.16 & $37.86^{\mathrm{b}}$ & $38.95^{\mathrm{b}}$ & $42.60^{\mathrm{a}}$ & 0.25 \\
\hline $\mathrm{P}_{4}(\mathrm{ng} / \mathrm{dl})$ & $3.61^{\mathrm{a}}$ & $3.43^{\mathrm{b}}$ & $3.18^{\mathrm{b}}$ & 0.01 & $1.25^{\mathrm{b}}$ & $1.49^{\mathrm{ab}}$ & $1.70^{\mathrm{a}}$ & 0.01 \\
\hline EST $17 \beta(\mathrm{pg} / \mathrm{ml})$ & $76.52^{c}$ & $99.54^{\mathrm{b}}$ & $106.31^{\mathrm{a}}$ & 2.75 & $34.15^{\mathrm{c}}$ & $39.84^{\mathrm{b}}$ & $43.67^{\mathrm{a}}$ & 0.35 \\
\hline
\end{tabular}

Means bearing different superscripts in the same raw are significantly different $(P<0.05)$.

$C=$ Control, $D F 3=3 \%$ DF (basedon DM intake) and DF5=5\% DF (basedon DM intake).

No significant differences $(\mathrm{P}<0.05)$ were observed in AST and ALT among the three groups over LP and PP (Table 7).Values of AST and ALT were within the normal range and indicated that the animals were generally in a good nutritional status and their livers were in a normal health condition. These results may explain that dry fat supplementation is safe with liver functions and so it had not any harmful effect on liver tissues .These results are in agreement with those obtained by Zeedan et al. (2010 and 2014) and Safaa (2015). 


\section{Zeedan et al.}

Data in Table (8) illustrated that glucose was increased significant with groups fed DF during LP and PP. These results also probably attributed to the higher of blood plasma glucose and albumin concentration of animals fed DF supplemented ration led to an increase in milk lactose synthesis and a consequent increase in milk production. These results are in accordance with Gabr et al. (2008), Zeedan et al. (2010 and 2014) and Safaa (2015). On the other hand, Singh et al. (2014) showed that blood glucose was similar in both the groups' treatment.

Supplemented groups had significantly higher concentrations of cholesterol, and total lipids than those of control one during LP and PP period. These results are in agreement with those reported by Gabr et al. (2008), Zeedan et al. (2010 and 2014) and Safaa (2015). Singh et al. (2014) showed that plasma cholesterol was increased $(\mathrm{P}<0.01)$ in prill fat supplemented cows over the control cows, but the values did not reach statistically significant. Accordingly, the elevated plasma total lipids concentration was accompanied with a significant increase in milk fat yield as pointed out in the present study. This increment in total lipid concentration exerted its effect on fat concentration of milk and the yield of milk fat in dairy buffalo's cows. Blood levels of total lipids and cholesterol reflected the in vivo metabolism of lipids, and strong lipid metabolism can release more energy to decrease the duration and magnitude of negative energy status.

Data in Table (8) illustrated that the HDL-cholesterol and LDL-cholesterol were significantly $(\mathrm{P}<0.05)$ increased during LP and PP periods with supplemented groups compared to control ration. These results are in accordance with Zeedan et al. (2014) and Safaa (2015). Singh et al. (2014) showed that plasma VLDL-Cholesterol increased in prill fat supplemented cows over the control cows. On the other hand, Singh et al. (2014) showed that plasma HDL-Cholesterol decreased in prill fat supplemented cows over the control cows, but the values did not reach statistically significant.

Concentrations of EST $17 \beta$ in blood of $\mathrm{DF}_{3}$ and $\mathrm{DF}_{5}$ groups were significantly greater $(\mathrm{P}<0.05)$ than that of C during two stages (late pregnancy LP and Postpartum PP) Table (8). Data also showed that level of plasma $\mathrm{P}_{4}$ was lower in treated groups in pre-partum period than that in the control group. Concentrations of $\mathrm{P}_{4}$ tended to change slightly during the postpartum first months where the ovaries are still inactive. Similar results were obtained by Zeedan et al. (2014). Staples and Thatcher (2001) reported that Cows fed fat produce or secrete more progesterone, a hormone necessary for the implantation and nutrition of the newly formed embryo. El-Garhir et al. (2013) reported significantly elevated $(\mathrm{P}<0.01)$ progesterone concentration $(\mathrm{ng} / \mathrm{ml})$ in blood serum of linseed seed whole group compared to whole cotton seed group and control group.

Generally the increase in blood constituents may be due to the role of fat in improving all nutrient digestibility especially $\mathrm{CP}$ and TDN (Table 3).Also, it may be probably led to an increase in the absorption rate from the digestive tract, thus blood constituents of the supplemented animals reflected a corresponding increase of these values.

\section{Reproductive performance}

Data concerning of some reproductive traits of the experimental dams are presented in Table (9). Treatments DF significantly $(\mathrm{P}<0.05)$ reduce the period of fetal membrane expulsion compared to the control group. Buffaloes of groups $\mathrm{DF}$ had significant shorter $(\mathrm{P}<0.05)$ intervals for uterine involution, onset of the $1^{\text {st }}$ heat and days open compared with control group. In consequence, groups $\mathrm{DF}_{3}$ and $\mathrm{DF}_{5}$ had the shortest $(\mathrm{P}<0.05)$ calving interval 412.70 and 374.60 days, respectively compared to $\mathrm{C}$ (421.30 days). On the contrary, the control group exhibited longer time to attain its uterine involution (51.23 days) or reaching conceptive dates (93.20 days). Buffaloes in groups DF required only one service to conceive. Gestation periods for Buffaloes-cow fed ration containing DF were relatively less than that of C group, presumably due to amelioration in fetal growth imposed by increased metabolism for the DCP, TDN at 50 days. This is in consistent with the results of Gabr et al. (2008), El-Garhir et al. (2013) and Zeedan et al. (2014). Staples and Thatcher (2001) showed that fat supplementation can increase the concentration of fat, cholesterol, and progesterone in blood and ovarian structures of ruminants as well as increase the size of ovulating follicles. Improved fertility may result from more progesterone being available to improve embryo survival and health of fat-fed cows.

Abu El-Hamd, et al., (2012) suggested that feeding Friesian cows during the $1^{\text {st }}$ and $2^{\text {nd }}$ parities on CFM supplemented with $5 \%$ protected fat recorded shorter post-partum service interval $(\mathrm{P}<0.001)$, service period $(\mathrm{P}<0.01)$ and days open $(\mathrm{P}<0.001)$, as well as less $(\mathrm{P}<0.01)$ number of services per conception. Ramteke, et al. (2014) indicated that dietary fats can provide fatty acids precursors for cholesterol and prostaglandin production, which have an effect on ovarian function, uterine function, and conception rates. There were two cases of dystocia, prolapsed of uterus and calf mortality. No such cases were observed in bypass fat (T2). Also, they found that days required for involution of uterus was reduced 
significantly $(\mathrm{P}<0.05)$ in bypass fat supplemented group. Reproductive disorders like retention of placenta, metritis and pyometra were also reduced to great extent. The service period and number of artificial insemination per conception was statistically $(\mathrm{P}<0.05)$ reduced in $\mathrm{T} 2$. In current study, improvement in reproductive traits may be due to an increase in the efficiency of nutrition absorption and/or nutrients utilization thus may be reflected on better animal performance production and reproductive.

Table (9). Means of some reproductive traits of buffaloes as affected by dry fat (DF) supplementation.

\begin{tabular}{lcccc}
\hline Item & \multicolumn{4}{c}{ Treatments } \\
\cline { 2 - 5 } & $\mathrm{C}$ & $\mathrm{DF}_{3}$ & $\mathrm{DF}_{5}$ & SEM \\
\hline Placental expulsion (hr) & $10.12^{\mathrm{a}}$ & $9.20^{\mathrm{b}}$ & $7.15^{\mathrm{c}}$ & 0.11 \\
Uterine involution (days) & $51.23^{\mathrm{a}}$ & $45.39^{\mathrm{b}}$ & $39.17^{\mathrm{c}}$ & 0.32 \\
Onset of $1^{\mathrm{c}}$ heat & $46.55^{\mathrm{a}}$ & $44.30^{\mathrm{b}}$ & $38.13^{\mathrm{c}}$ & 0.53 \\
No services / conception & $3.10^{\mathrm{a}}$ & $1.88^{\mathrm{b}}$ & $1.00^{\mathrm{c}}$ & 0.01 \\
Days open & $93.20^{\mathrm{a}}$ & $89.20^{\mathrm{b}}$ & $69.60^{\mathrm{c}}$ & 0.60 \\
Gestation period (days) & $328.10^{\mathrm{a}}$ & $323.50^{\mathrm{a}}$ & $305.00^{\mathrm{b}}$ & 10.85 \\
Calving interval (days) & $421.30^{\mathrm{a}}$ & $412.70^{\mathrm{b}}$ & $374.60^{\mathrm{c}}$ & 5.12 \\
\hline
\end{tabular}

Means bearing different superscripts in the same raw are significantly different $(P<0.05)$.

$C=$ Control, $D F_{3}=3 \% D F$ (basedon DM intake) and $D F_{5}=5 \% D F$ (basedon DM intake).

\section{Pregnancy rate}

Data in Table (10) showed that two buffaloes from the control group came in heat after 60 days after delivery, two of them ovulated and two conceived. In the $\mathrm{DF}_{3}$ group three buffalo cows came in heat after 60 days after delivery, three of them ovulated and three conceived. While the $\mathrm{DF}_{5}$ group, five buffalo cows came in heat after 60 days after delivery, and five animals were ovulated and five conceived. Results revealed higher pregnancy rate in $\mathrm{DF}_{3}$ and $\mathrm{DF}_{5}(60 \%$, and $100 \%)$ than $\mathrm{C}(40 \%)$ which was due to dry fat addition, being better with $\mathrm{DF}_{3}$ and $\mathrm{DF}_{5}$ than $\mathrm{C}$. The improvement of ovulated and pregnancy rate may be due to increased metabolism for the DCP and TDN at 50 and 180 days thus led to an increase in utilization of rations. Also, animal feed $\mathrm{DF}_{3}$ at 90 day all animal ovulated and conceived, pregnancy rate in $\mathrm{DF}_{3}(100 \%)$, while $\mathrm{C}$ was $(66.67 \%)$. With, at 120 day the rest of the animals in the group $\mathrm{C}$ were ovulated and conceived.

Table (10). Conception rate (\%) of buffalo cows as affected by dry fat (DF) supplementation.

\begin{tabular}{|c|c|c|c|c|c|c|c|c|c|}
\hline \multicolumn{10}{|c|}{ Response of treatment } \\
\hline Groups & NO. & \multicolumn{2}{|c|}{ Heat } & \multicolumn{2}{|c|}{ Standing } & \multicolumn{2}{|c|}{ Ovulation } & \multicolumn{2}{|c|}{ Conception } \\
\hline At 60 days & & & & & & & & & \\
\hline & & NO & $\%$ & NO & $\%$ & NO & $\%$ & NO & $\%$ \\
\hline $\mathrm{C}$ & 5 & $2(2 / 5)$ & 40 & $2(2 / 5)$ & 40 & $2(2 / 5)$ & 40 & $2(2 / 5)$ & 40 \\
\hline $\mathrm{DF}_{3}$ & 5 & $3(3 / 5)$ & 60 & $3(3 / 5)$ & 60 & $3(3 / 5)$ & 60 & $3(3 / 5)$ & 60 \\
\hline $\begin{array}{l}\mathrm{DF}_{5} \\
\text { At } 90 \text { days }\end{array}$ & 5 & $5(5 / 5)$ & 100 & $5(5 / 5)$ & 100 & $5(5 / 5)$ & 100 & $5(5 / 5)$ & 100 \\
\hline $\mathrm{C}$ & 5 & $3(3 / 3)$ & 100 & $3(3 / 3)$ & 100 & $3(3 / 3)$ & 100 & $2(2 / 3)$ & 66.67 \\
\hline $\mathrm{DF}_{3}$ & 5 & $2(2 / 2)$ & 100 & $2(2 / 2)$ & 100 & $2(2 / 2)$ & 100 & $2(2 / 2)$ & 100 \\
\hline $\begin{array}{l}\mathrm{DF}_{5} \\
\text { At } 120 \text { days }\end{array}$ & 5 & - & - & - & - & - & - & - & - \\
\hline $\mathrm{C}$ & 5 & $1(1 / 1)$ & 100 & $1(1 / 1)$ & 100 & $1(1 / 1)$ & 100 & $1(1 / 1)$ & 100 \\
\hline $\mathrm{DF}_{3}$ & 5 & - & - & - & - & - & - & - & - \\
\hline $\mathrm{DF}_{5}$ & 5 & - & - & - & - & - & - & - & - \\
\hline
\end{tabular}

The marked improvement in pregnancy rate of buffaloes supplementation with DF especially with $\mathrm{DF}_{5}$ compared with $\mathrm{C}$ is in agreement with the findings of Gabr et al. (2008), Zeedan et al. (2010 and 2014). Staples and Thatcher (2001) reported that the feeding of additional energy in the form of fat reduces the cow's negative energy status so that returns to estrus earlier after calving and therefore 


\section{Zeedan et al.}

conceives sooner. Cows fed fat produce or secrete more progesterone, a hormone necessary for the implantation and nutrition of the newly formed embryo. Specific individual long chain fatty acids found in some fats inhibit the production or release of prostaglandin $\mathrm{F}_{2 \alpha}\left(\mathrm{PGF}_{2 \alpha}\right)$ by the uterus. This prevents the regression of the corpus luteum $(\mathrm{CL})$ on the ovary so that the newly formed embryo survives. If fat supplementation can help increase energy intake, then possibly the negative energy state can be lessened and estrous cycles resume sooner. Also, they reported that fat supplementation can increase the concentration of fat, cholesterol, and progesterone (Progesterone is synthesized from cholesterol) in blood and ovarian structures of ruminants as well as increase the size of ovulating follicles. Improved fertility may result from more progesterone being available to improve embryo survival and health of fat-fed cows. Ramteke, et al. (2014) found that protected fat during prepartum and early lactation significantly improved the onset of first postpartum heat, service period and number of artificial insemination (AI) per conception was significantly reduced due to feeding of rumen protected fat. Dietary fats can provide fatty acids precursors for cholesterol and prostaglandin production, which havens effect on ovarian function, uterine function, and conception rates.

\section{Health status of delivered calves}

Dams in control group delivered only 3 calves because there was one case of abortion and one case of stillbirth, meanwhile, treated dams delivered 10 healthy calves (Table 11).The calves from treated DF dams showed higher birth weight $(\mathrm{CBW})$, weaning weight and total daily gain, and better vitality in comparison with the $\mathrm{C}$ as shown in Table (5).

Table (11). Mean values of health status of newborns of buffaloes treated with dry fat (DF) supplementation.

\begin{tabular}{lccc}
\hline Item & \multicolumn{3}{c}{ Health status of delivered calves } \\
\cline { 2 - 4 } & $\mathrm{C}$ & $\mathrm{DF}_{3}$ & $\mathrm{DF}_{5}$ \\
\hline Aborted feti & 1 & 0 & 0 \\
Still birth & 1 & 0 & 0 \\
Mortality at $1^{\text {st }}$ month & $2 / 5(40 \%)$ & $0 / 5(0 \%)$ & $0 / 5(0 \%)$ \\
Survival rate & $3 / 5(60 \%)$ & $5 / 5(100 \%)$ & $5 / 5(100 \%)$ \\
\hline Means bearing different superscripts in the same raw are significantly different $(P<0.05)$. & \\
$C=$ Control, $D F_{3}=3 \%$ DF (basedon DM intake) and $D F_{5}=5 \%$ DF (basedon DM intake).
\end{tabular}

In addition, no mortality in the $1^{\text {st }}$ month was occurred between the newborn calves resulted from DF treated buffaloes compared to the control group. Moreover, the control calves showed more severe pneumonia and enteritis as a result of which two (40\%) calves were died. It is suggested that the supplementation of DF had improved the thyroid function at calving and weaning in the buffaloes, increased the digestible protein, TDN (50 and 180 days), milk protein and milk lactose led to increase the calf birth weight and calf weaning weight. The growth of calves before weaning is dependent upon 2 factors, the high quality of colostrums and feeding management to stimulate rumen growth. These two factors may be responsible to the higher growth rate of the calves born from the treated by addition of DF for buffaloes cows. The supplementation DF buffalo's cows might have a better quality of colostrums; since their calves were born with a higher BW, they consumed more colostrums than those with lower BW. These results are in agreement with those obtained by Zeedan et al. (2014). Zeedan et al. (2010) showed that higher $(\mathrm{P}<0.05)$ birth weight values kids born from of does fed DF rations compared with control group. Also, they found that may be related to sufficient metabolizable energy provided by the supplemented fat which could stimulate greater fetal growth and consequently increase birth weight as well as weaning weight. Ramteke, et al. (2014) indicated that protected fat $\left(\mathrm{T}_{2}\right)$ during prepartum and early lactation significantly improved the birth weight of the calf. Higher birth weight of the calves observed in $\mathrm{T}_{2}$ may be due to the higher energy intake due to addition of bypass fat. Also, they reported that the higher progesterone level may be responsible for better nourishment of fetus in the final stages of pregnancy. Also; increased globulin concentration with addition of DF inclusion which was observed in the present study may be an indication of increased immunity in the buffalo's cow since the liver will be able to synthesize enough globulins for immunologic action.

\section{Economic efficiency}

Data of Table (12) indicated that the best economical efficacy was obtained (1.44) in animals fed ration supplemented with $\mathrm{DF}_{5}$ that the highest milk yield followed by 1.42 for $\mathrm{C}$, while 
the lowest one (1.37) was obtained for buffaloes-cow in the $\mathrm{DF}_{3}$ group. These results are in agreement with those recorded by Zeedan et al. (2014) and Safaa (2015).

Table (12). Economical efficiency of lactating Egyptian buffalo cows as affected by dry fat (DF) supplementation.

\begin{tabular}{|c|c|c|c|}
\hline Item & C & $\mathrm{DF}_{3}$ & $\mathrm{DF}_{5}$ \\
\hline \multicolumn{4}{|l|}{ Daily consumption $(\mathrm{kg})$} \\
\hline CFM & 7.57 & 7.57 & 7.57 \\
\hline $\mathrm{BH}$ & 4.43 & 4.43 & 4.43 \\
\hline R.S & 3.30 & 3.10 & 2.70 \\
\hline dry fat (DF) (g) & - & 414 & 670 \\
\hline Total cost LE & 41.96 & 47.69 & 51.11 \\
\hline Actual milk yield, kg / day & 8.50 & 9.30 & 10.50 \\
\hline Price of daily Actual milk yield & 59.50 & 65.10 & 73.50 \\
\hline Profit above feeding cost (LE) & 17.54 & 17.41 & 22.39 \\
\hline Feed cost / kg Price of daily Actual milk (LE) \% & 70.52 & 73.26 & 69.54 \\
\hline Economic efficiency* & 1.42 & 1.37 & 1.44 \\
\hline \multicolumn{4}{|c|}{$\begin{array}{l}\text { Price of feedstuffs }(\text { LE / ton) for 2016: concentrate feed mixture }=4200 \text {, berseem hay }=2000 \text {, and rice straw }=400 \text {, } \\
D F=14000, \text { wherever } k g \text { of milk of buffaloes was }=7 \text { LE. *Economic efficiency }=\text { Price of Actual milk }(\text { LE) } / \text { Total } \\
\text { feed cost }(L E) \text {. }\end{array}$} \\
\hline$C=$ Control,$D F_{3}=3 \% D F($ basedon DM intake $)$ and $D$ & basedon & intake). & \\
\hline
\end{tabular}

\section{CONCLUSION}

The results of this study revealed that, supplementation of dry fat (DF) to ration of lactating buffalocows at different levels ( 3 or 5\%) tended to improve the rumen fermentation, digestion, nutritive values, actual milk yield (AMY) and 7\% fat corrected milk (7\% FCM) yield and its composition, beside better feed efficiency and reproductive performance as well as improved economic efficiency under the Egyptian conditions despite mounting various input prices compared to international prices, but they were the best and the highest results with the addition of $\mathrm{DF}_{5}$. Using fat can avoid some problem such as ruminal acidosis and liver abscess.

\section{REFERENCES}

Abu El-Hamd, M. A. Ewada, N. and Noura, B. A. Bayoumy (2012).Effect of protected fat on productive and reproductive performance of Friesian lactating cows during postpartum period. Egyptian J. Anim. Prod., 49:65-72.

AOAC. (1995). Official Methods of Analysis $15^{\text {th }}$ ed. Association of Official Analytical Chemists. Arlington, Virginia, USA.

Duncan, D.B. (1955). Multiple range and multiple F- tests. Biometrics., 11: 1-42.

Eadie, J. M.; P.N. Hobson and S. O. Mann (1967). A note on some comparison between the rumen content of barley fed steers and that young calves also fed on high concentrate rations. J. Anim. Prod., 9:247.

El-Garhir, M.S. E.Y. Ismail, N.F. Khaled and M.M. El-Garhia (2013).effect of feeding ration based on whole linseed or whole cotton sbeds on reproductive performance of dairy buffalo cows. Egyptian. J. Nutr. and Feeds. 16 (2): 9-18.

FAO (1990).Production year book. Rome, Italy, FAO, 420 p. (No. 49).

Fiorentini, G., I. P. C. Carvalho, J. D. Messana, P. S. Castagnino, A. Berndt, R. C. Canesin, R. T. S. Frighetto and T. T. Berchielli (2014). Effect of lipid sources with different fatty acid profiles on the intake, performance, and methane emissions of feedlot Nellore steers. J. Anim. Sci. 92:1613-1620.

Gabr, A. A.; M. M. El-Shinnawy; B.E. EI-Saidy and M.M. El-Badawy (2008). Influence of diets supplemented with fish oil on nutrients digestibility, some rumen parameters, blood constituents, productive and reproductive performance of ewes. J. Agric. Sci. Mansoura Univ., 33(2):991-1007. 


\section{Zeedan et al.}

Hafez, Y.M. (2012). Enhancing milk production in periparturient buffalo fed protected fat with and without vitamin $\mathrm{AD}_{3} \mathrm{E}$ treatment. Egyptian J. Anim. Prod. 49 (3):249-256.

Hassanien, M.R. (2010). Effect of fat supplementation on performance of sheep. M. Sc. Thesis. Anim. Prod. Dept. Menoufia.

Kearl. L.C. (1982). Nutrient requirements of ruminants in developing countries. International feedstuffs Institute, Utah Agrie. Expt. Stat. Utah State Univ., USA.

Kholif, S. M.; T. A. Morsy; O. H. Matloup; H. M. Ebeidl and A. M. Kholif (2015). Effects of crushed linseed or linseed oil supplementation on performance of dairy goats and fatty acid profile in milk. Life Sci. J.; 12(2s): 94-99.

Madan, J., N. Saxena, C. Mohan, R. Kumar, K. Kumar and D. Lal (2013). Field study on protected fat feeding during summer season on milk yield and milk composition in buffaloes. Haryana Vet.52: 9395.

National Research Council (NRC). (2001). Nutrient requirements of dairy cattle (7th ed., p. 381). Washington, D.C.: National Academy Press.

Overman, O. R. and F. P. Sanmann (1926). The energy of milk as related to composition $3{ }^{\text {rd }}$ Agric. Exp. Sta. Bull., 282.

Raafat, M. A and M. S. Saleh (1962). Two formulas for the conversion of cow's and buffalo's milk of different percentages into milk of standard fat percentage. Proceeding of the $1^{\text {st }}$ Anim. Prod. Conf. Minia, 203.

Ramteke, P.V., Patel, D.C., Parnerkar, S., Shankhpal, S.S., Patel, G.R. and Pandey, A. (2014). Effect of bypass fat supplementation during prepartum and postpartum on reproductive performance in buffaloes. Livestock Res. Int. 2 (3):54-58.

Rennó,F. P., F. J. Júnior, J. R. Gandra, M. M. Filho, L.C. Verdurico, L. N. Rennó, R. V. Barletta and F. G.Vilela (2014). Effect of unsaturated fatty acid supplementation on digestion, metabolism and nutrient balance in dairy cows during the transition period and early lactation. R. Bras. Zootec. 43(4):212-223.

Safaa, E. S. A. (2015). The effect of the using of dry fat on productive performance of Egyptian dairy buffaloes. Ms. D. Thesis. Anim. Prod. Dept. Uni. Tanta.

Singh, M., J. P. Sehgal, A. K. Roy, S. Pandita and G. Rajesh (2014). Effect of prill fat supplementation on hormones, milk production and energy metabolites during mid lactation in crossbred cows. Vet. World 7(6): 384-388.

Sharma, S., Singh, M., Roy, A.K. and Thakur, S. (2016). Effect of pre-partum prilled fat supplementation on feed intake, energy balance and milk production in Murrah buffaloes. Vet. World, 256-259.

Souza Júnior, A. H., Paula Lana, R., Viana Teixeira, Gionbelli, C.R.M. P., Cristina Veloso, M. and Rennó, L. N. (2016). Protected fat and variable level of protein in diets of crossbreed cows in early lactation. Maringá, 38(1): 107-112.

SPSS (2012). SPSS User's Guide Statistics Version 19. Copyright IBM, SPSS Inc., USA.

Staples, C. R. and W. W. Thatcher (2001). Nutrient influences on reproduction of dairy cows. In Proceedings of Mid-south Ruminant Nutrition Conference (pp. 21-35).

Toufighi , K., Ahangari, Y. J., Rouzbehan, Y., and Karimi, K.,(2014).Effect of rumen-protected fat on performance and serum concentration of T3 hormone of Holstein young bulls during hot, humid weather. Ital J Anim Sci. 13:371-321.

Van Keulen, 1. and B. A. Young (1977). Evaluation of acid insoluble ash as a natural marker in ruminant digestibility studies. J. Anim. Sci., 44(2): 282.

Zeedan, Kh. I. I., Abdel-Latif, M.A., El-Bltagy, E.A. and El-monayer, T.I. (2014). Effete the addition of oil and dry fat on productive and reproductive performance on Egyptian buffaloes - cow's ration. Egyptian J. Nut. and Feeds 17 (3): 457- 472.

Zeedan, Kh. I.I., O.F. Komonna, K.E.I. Etman and Kh. M. M. Mousa (2010). Effect of using different levels and sources of fats and roughages on productive performance, rumen fermentation and some blood parameters in ruminant. 1- Effect of dry fat supplementation on productive and reproductive performance of Damascus goats. Egyptian J. Nut. and Feeds 13 (1): 21-40 


\title{
تاتير إضافة الاهن الجاف على الاداء الانتاجى والتناسلى فى الجاموس الحلاب
}

خالد إبراهيم إبراهيم زيدان1، مجدى عبد الرحمن عبد الطيف2، عزت عرفة البلتاجى ، سليمان ولد عبد القادر ابراهيم،

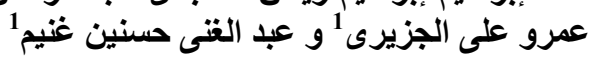

\author{
1 قسم بحوث تظذية الحيوان ، 2 قسم بحوث تربية الجاموس ، 3 قسم بحوث استخام المخلفات

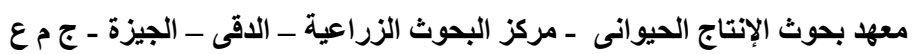

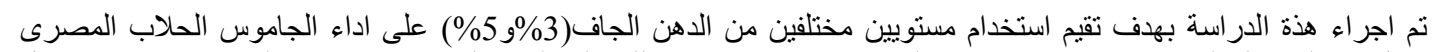

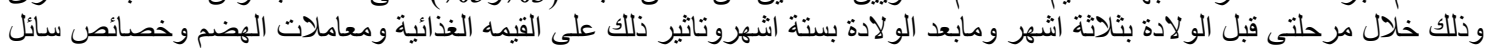

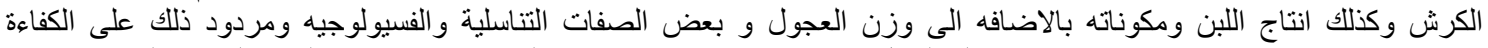

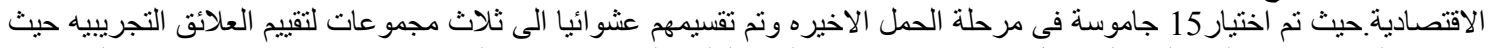

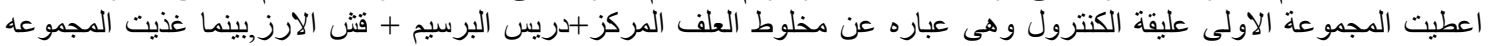

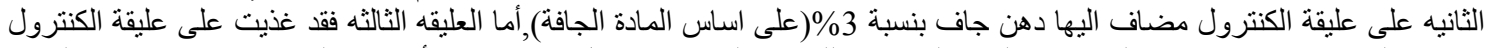

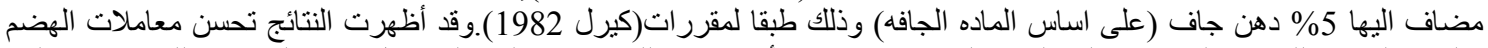

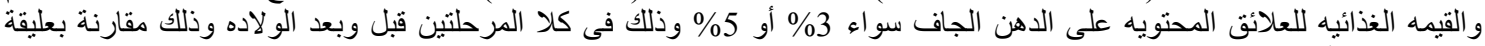

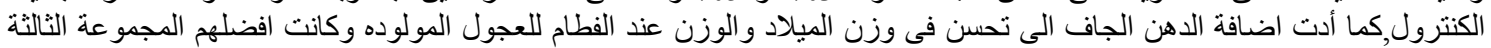

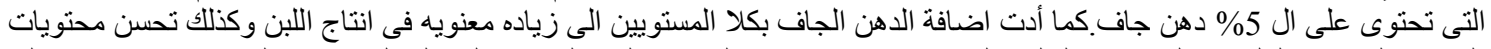

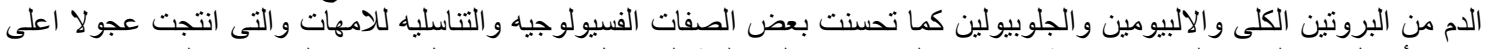

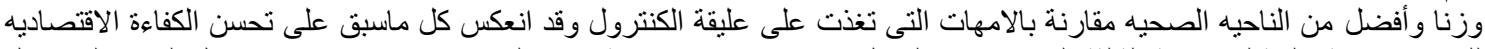

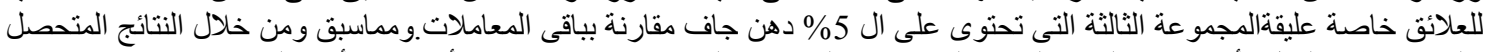

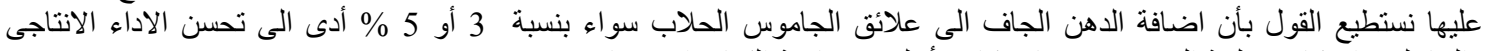
و التناسلى وان كانت عليقة ال5\% دهن جاف كانت أعلى من ناحية الكفاءه الاقتصاديه. 